\title{
ADJUSTMENT PROCESSES \\ IN SELECTED TYPES OF FARMS DEPENDING ON THEIR INCOME SITUATION
}

\author{
WOJCIECH JÓZWIAK \\ ZOFIA MIRKOWSKA \\ JOLANTA SOBIERAJEWSKA \\ MAREK ZIELIŃSKI \\ WOJCIECH ZIETTARA
}

\begin{abstract}
This article presents the development capacities of farms in groups divided according to the level of income from farm per unit of work of a farmer and farmer's family members. According to the income criterion, farms were separated into:

- auxiliary in which income from the farm per hour of family work input in the owned farm was lower than the level of payment for employed labour in agriculture;

- transitional ("at the crossroads") in which this income was higher than the level of payment for employed labour in agriculture, but lower than the rate of payment in the national economy;

- developmental in which this income was equal to or higher than the rate of payment for labour in the national economy.

The analysis covered types of farms specialised in: field crops, permanent crops, vegetable crops, dairy cattle raising, granivores raising, and mixed production. The source of research materials was the panel of farms covered by the monitoring of the Polish FADN in 2009-2016. Groups were separated according to the FADN methodology. The development capacities of the analysed farm
\end{abstract}

\footnotetext{
The authors are employees of the Institute of Agricultural and Food Economics - National Research Institute, Economics of Farm Holdings Department; ul. Świętokrzyska 20, 00-002 Warsaw. Prof. dr hab. Wojciech Józwiak (jozwiak@ierigz.waw.pl); ORCID iD: 0000-0002-5358-261X. Mgr Zofia Mirkowska (zmirkowska@ierigz.waw.pl); ORCID iD: 0000-0002-6241-1054.

Mgr Jolanta Sobierajewska (sobierajewska@ierigz.waw.pl); ORCID iD: 0000-0002-5161-696X.

Dr Marek Zieliński (zielinski@ierigz.waw.pl); ORCID iD: 0000-0002-6686-5539.

Prof. dr hab. Wojciech Ziętara (zietara@ierigz.waw.pl); ORCID iD: 0000-0002-3182-522X.
} 
groups were determined with the competitiveness index (CI). In the analysed period, the share of auxiliary farms was significant, ranging from $24.5 \%$ (dairy farms) to $43.1 \%$ (farms with mixed production). This share increased in subsequent periods. These farms did not have development capacities. The share of transitional farms was small, ranging from $8.5 \%$ (field crops) to $13 \%$ (with mixed production). Farms in this group also did not show developmental capacities. The share of developmental farms was quite varied, ranging from $44.4 \%$ (with mixed production) to $69 \%$ (with field crops). The applied criterion for the division of farms according to the level of income from farm per unit of work of a farmer and farmer's family members increases the possibilities of their analysis.

Keywords: agricultural holdings, income from farm, auxiliary, transitional and developmental farms, types of farming.

JEL codes: Q12, Q13, Q15.

\section{Introduction}

The integration of Poland with the European Union in 2004 increased the pace of economic changes initiated by the change in the political and economic system in 1989. The essence of the changes was the implementation of market economy principles. The introduction of the market system caused a diversification of the growth rate of prices of production factors and prices of products, including agricultural ones. Labour costs in the national economy were increasing the most significantly (wages are their main component), resulting in increased labour costs in agriculture. The increase in prices of means of production purchased by farmers was slightly weaker, and in the sales prices of agricultural products sold by farmers the least dynamic. This is illustrated by the following figures: in 1995-2016, labour costs in the national economy increased more than six times, prices of means of production more than three times, and sales prices of agricultural products more than two times (Runowski, 2018; Ziętara and Mirkowska, 2019). The diverse rate of price increase caused a decrease in the unit profitability of agricultural production. Farmers were subjected to strong pressure to increase production efficiency. The phenomenon of the so-called technology treadmill of W. Cochrane also occurred, according to which, despite an increase in agricultural productivity, farmers' incomes do not increase at the same pace, and even decrease (Czyżewski, 2017). One of the ways to increase production efficiency is specialisation of agricultural holdings, which is additionally forced by recipients of products, demanding large, uniform batches. Brinkmann already took note of this issue formulating the "force theory"1 affecting farms (Brinkmann, 1922). The importance of specialisation in

\footnotetext{
${ }^{1}$ T. Brinkmann distinguished two types of forces: "Integrierte Kräfte" and "Diferenzierte Kräfte". The first type is the integrating force on the farm, forcing it to multilateral production in order to evenly and fully use the production factors. Whereas differentiating force occurs in the market environment and forces farms to specialise in production. Differentiating force currently plays a greater role.
} 
improving the farming efficiency was also emphasised by Manteuffel who stated: "Specialisation is aimed at increasing the size of the basic activity, the one which defines the specialisation and thus increases the productivity of work in the activity determining specialisation" (Manteuffel, 1981, p. 160).

Therefore, the questions about specialisation processes in Polish agricultural holdings become valid. What directions of production are there? What is the degree of competitiveness of farms pursuing given directions of production?

In order to find answers, the systematics of farms used by the Polish FADN was used ${ }^{2}$ (Bocian, Osuch and Smolik, 2018). For research purposes, the following types of farming (TF8) of holdings were identified: field crops (1), horticultural (vegetable) crops (2), permanent crops (4), dairy cattle raising (5), herbivores raising (6), granivores raising (7), and mixed productions (8). Vineyards, which are scarce in Poland and not included in the monitoring of the Polish FADN, have been omitted. Table 1 presents the number and structure of agricultural holdings in Poland in 2013-2016 by types of farming. Due to the lack of data, dairy cattle and herbivores are included in Table 1 as "raising of grazing animals."

Table 1

Number and structure of farms by type of farming in 2013-2016

\begin{tabular}{|c|c|c|c|c|c|c|c|c|}
\hline \multirow[b]{2}{*}{ Years } & \multicolumn{8}{|c|}{ Types of farming of holdings (number in thous. and structure in \%) } \\
\hline & Total & $\begin{array}{l}\text { Field } \\
\text { crops }\end{array}$ & $\begin{array}{l}\text { Vegetable } \\
\text { crops }\end{array}$ & $\begin{array}{l}\text { Permanent } \\
\text { crops }\end{array}$ & $\begin{array}{l}\text { Grazing } \\
\text { animals }\end{array}$ & $\begin{array}{l}\text { Granivorous } \\
\text { animals }\end{array}$ & $\begin{array}{c}\text { Mixed } \\
\text { productions }\end{array}$ & Unclassified \\
\hline \multirow{2}{*}{2013} & 1429.0 & 702.9 & 26.5 & 63.9 & 162.1 & 35.8 & 407.8 & 30.0 \\
\hline & 100.0 & 49.2 & 1.9 & 4.5 & 11.3 & 2.5 & 28.5 & 2.1 \\
\hline \multirow{2}{*}{2016} & 1410.7 & 797.4 & 26.1 & 58.1 & 154.5 & 32.5 & 317.9 & 24.2 \\
\hline & 100.0 & 56.5 & 1.9 & 4.1 & 10.9 & 2.3 & 22.6 & 1.7 \\
\hline \multicolumn{9}{|c|}{ Economic size (thou. EUR SO/farm) } \\
\hline 2016 & 16.1 & 8.3 & 70.4 & 25.8 & 30.9 & 115.9 & 15.7 & . \\
\hline \multicolumn{9}{|c|}{ Area of the farm (ha UAA/farm) } \\
\hline 2016 & 9.4 & 8.6 & 5.6 & 6.2 & 16.0 & 11.8 & 8.5 & 3.0 \\
\hline
\end{tabular}

Source: Statistics Poland, 2014; 2017.

The numbers presented in Table 1 allow the following statements:

- in 2013-2016, the total number of farms decreased by 18.3 thous. (1.3\%), from 1429.0 thous. in 2013 , to 1410.7 thous. in 2016 ;

- the number of unclassified farms and farms with mixed production decreased the most - by $19.3 \%$ and $22.0 \%$, respectively. The number of farms in the "permanent crops" and "herbivorous animals" types decreased by $9.1 \%$ and $9.2 \%$, respectively, while in the "horticultural (vegetable) crops" and "graz-

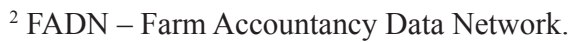


ing animals" types by $1.5 \%$ and $4.7 \%$, respectively. However, the number of farms in the "field crops" type increased by $13.4 \%$;

- the structure of farms changed. The share of farms in the "field crops" type dominated and increased in the studied years: from $49.2 \%$ to $56.5 \%$. The share of farms in the "mixed" type was significant, and in extreme years amounted to $28.5 \%$ and $22.6 \%$. The participation of the "vegetable crops," "permanent crops," "granivores" types and unclassified farms was stable or relatively stable, and amounted to $1.9 \% ; 4.5 \%$ and $4.1 \% ; 2.5 \%$ and $2.3 \%$ and $2.1 \%$ and $2.7 \%$, respectively. The share of farms with "grazing animals" type was larger and quite stable. This share was $11.3 \%$ and $10.9 \%$;

- the economic size of farms in the specified types was expressed in thous. EUR of SO. ${ }^{3}$ The average economic size of farms in total in 2016 was 16.1 thous. EUR of SO. According to this criterion, the largest farms were those in the "granivorous" type (115.9 thous. EUR of SO) and with vegetable crops (70.4 thous. EUR of SO). Farms with raising of grazing animals and permanent crops were similar in terms of their economic size, where it amounted to 30.9 and 25.8 thous. EUR of $\mathrm{SO}$, respectively. Farms with field crops and mixed production were the smallest - their average size was 8.3 and 15.7 thous. EUR of SO;

- the degree of diversity of the area of farms in the separated agricultural types was definitely lower. In 2016, the average area of farms in total was 9.4 ha of utilised agricultural area. Farms raising grazing animals and granivorous animals were larger than the average with an area of 16.0 and 11.8 ha of UAA, respectively. The area of other farms was smaller than the average. Unclassified farms had the smallest area -3.0 ha of UAA. It is worth emphasising the small area of farms in the "field crops" type which in 2016 was 8.6 ha. Over 50\% of farms in this type was using less than 5 ha of UAA. They had the character of auxiliary farms (Józwiak, 2017).

\section{Objective of research, research methods and sources of research materials}

The objective of the study is to determine the development capacities of selected types of farming of agricultural holdings, taking into account the level of income obtained from farm per unit of work of a farmer and farmer's family members on the owned farm. The research covered the following types of farming: field crops, dairy cattle, permanent (orchard) crops, horticultural (vegetable) crops and mixed production, in accordance with the methodology of the Polish FADN. ${ }^{4}$ The develop-

\footnotetext{
${ }^{3} \mathrm{SO}$ - Standard Output - standard production value expressed in thous. EUR, calculated as the average value of production from individual production activities over a period of five years in a given region. According to the economic size, six classes of farms were distinguished: very small (2-8 thous. EUR of SO), small (8-25 thous. EUR of SO), medium small (25-50 thous. EUR of SO), medium large (50-100 thous. EUR of SO), large (100-500 thous. EUR of SO) and very large ( $>=500$ thous. EUR of SO) (Bocian, Osuch and Smolik, 2018).

${ }^{4}$ Analysis within the "grazing" type covered "dairy cattle" as the basic type. The "granivorous" type was omitted as including poultry and pigs.
} 
ment capacities of farms of the studied types of farming were determined according to the level of income from farm per unit of work of a farmer and farmer's family members. The full justification for such a classification of farms is presented in the article "The level of labour profitability and development opportunities of agricultural holdings in Poland" (Józwiak, Sobierajewska, Zieliński and Ziętara, 2019).

Calculation of income from farm per family work unit (man-hour, $\mathrm{MH}$ ) makes it possible to assess its level by reference to the remuneration of employed labour in agriculture (income parity A) and in the national economy (income parity B). Considering the level of income from farm per unit of work of a farmer and farmer's family members on the farm, the studied entities were divided into three classes: auxiliary, transitional and developmental. "Auxiliary" farms are those in which income from farm per family work unit is lower than the payment for employed labour in agriculture, which means that the farmer does not achieve parity A. In this class, the share of income from farm was less than $50 \%$ of total income of a farming family (Józwiak, Mirkowska and Ziętara, 2018).

Due to the fact that a unit income obtained from the work on the farm is smaller than the level of parity A, the farmer is confronted with the problem of whether to continue running the farm or give up and try to take up a job as a hired worker. The possibilities for farmers using farms in this class to find work outside the farm are limited, although they have been growing recently. They depend on the qualifications and the condition of the economy in the immediate environment (Sikorska, 2013). A farmer who resigns from running a farm may take up a job as a hired worker at another farmer, accepting the level of remuneration of employed workers in agriculture (parity A). There is also a situation that a farming family receiving a unit income from work on the farm owned lower than the level of parity A does not give up running their farm, but its members undertake paid employment outside it as employed people, and at the same time the production is reorganised or modernised with support from the RDP (Józwiak, 2017). In the first case observed more frequently (Dudek, 2016), the production is simplified resulting in a reduction of labour input on the farm and an increase in agricultural income per unit of labour input. However, the income from farm is decreasing. The second case occurs less frequently (Dudek, 2016; Żmija, 2016), but results in an increase in income from farm.

In "transitional" farms "at the crossroads" the income from farm is higher than the level of parity A, but lower than parity B, whereas in "developmental" farms, the income from farm is equal to or higher than the level of parity B. A characteristic feature of the auxiliary class is that their number decreases over longer periods (Józwiak, 2017). Transitional farms (at the crossroads) have limited development capacities. Analysing the group of transitional farms in longer periods, it is hard not to see that its number is supplied by developing auxiliary farms, and the economically active part of transitional farms goes to the developmental group. The number of developmental farms usually increases year by year (Józwiak, 2017). 
The panel of farms covered by the monitoring of the Polish FADN in 2009-2017 was used as the basic source of research materials. The panel includes 5471 farms, i.e. $45.6 \%$ of the population of farms covered by the monitoring of the Polish FADN every year. The study was carried out taking into account mean values from the following three-year periods: 2009-2011; 2012-2014 and 2015-2017. Three-year periods were adopted to avoid annual fluctuations. The number of farms in the analysed types and years including the economic size is given in Table 2. The distribution of the number of the studied farms was strongly asymmetrical. About $98.6 \%$ of farms were in the economic size classes from small (EUR 8-25 thous. of SO) to large (EUR 100-500 thous. of SO). The class of very small farms (EUR 2-8 thous. of SO) included 73 farms (1.3\%), while the class of very large farms (EUR 500 thous. of SO and more) only 5 farms. Due to the small number, these extreme groups were excluded from the studied population. Ultimately, the population numbered 5,393 farms.

Farms with the mixed production type were the most numerous in the studied population. Their share was $36.9 \%$. The share of farms with field crops and raising dairy cattle was slightly lower, and in the analysed period amounted to $27.0 \%$ and $21.3 \%$, respectively. Farms with permanent and vegetable crops were the least numerous; their number was 180 and 164 farms, respectively, and their share was 3.3\% and 3.0\%, respectively. Small farms (up to EUR 25 thous. of SO), medium small (EUR 25-50 thous. of SO) and medium large (EUR 50-100 thous. of SO) were more strongly represented in all types analysed. The distribution of farms with vegetable crops was more even. In all types except for vegetable crops and mixed production, the number and share of large farms increased in subsequent periods.

Table 3 shows the unit payment for hired labour on farms by type of farming, the level of payment for work in the national economy and the interest rate on long-term bonds in 2009-2017. For the distinguished 3-year periods, the average payment for hired labour in agriculture and in the national economy was calculated per 1 hour of work of FWU. 
Table 2

Changes in the number of studied farms by types of farming and economic size in 2009-2017

\begin{tabular}{|c|c|c|c|c|c|c|c|c|}
\hline \multirow{2}{*}{$\begin{array}{l}\text { Types of } \\
\text { farming }\end{array}$} & \multirow{2}{*}{ Years } & \multicolumn{7}{|c|}{ Economic size classes of farms (thous. EUR SO) } \\
\hline & & $2-8$ & $8-25$ & $25-50$ & $50-100$ & $100-500$ & $>=500$ & Total \\
\hline \multirow[t]{3}{*}{ Field crops } & 2009-2011 & 7 & 322 & 394 & 351 & 199 & 2 & 1275 \\
\hline & $2012-2014$ & 18 & 392 & 429 & 357 & 229 & 2 & 1427 \\
\hline & $2015-2017$ & 49 & 392 & 454 & 409 & 258 & 3 & 1670 \\
\hline On average & $2009-2017$ & 24 & 404 & 426 & 373 & 228 & 2 & 1457 \\
\hline \multirow{2}{*}{ Dairy cattle } & $2009-2011$ & 3 & 165 & 473 & 383 & 103 & - & 1127 \\
\hline & $2012-2014$ & 4 & 161 & 454 & 415 & 131 & - & 1165 \\
\hline \multirow{2}{*}{ On average } & $2015-2017$ & 5 & 144 & 419 & 421 & 172 & - & 1161 \\
\hline & $2009-2017$ & 4 & 157 & 449 & 406 & 135 & - & 1151 \\
\hline \multirow{3}{*}{$\begin{array}{l}\text { Permanent } \\
\text { crops }\end{array}$} & 2009-2011 & 3 & 81 & 62 & 20 & 4 & - & 170 \\
\hline & $2012-2014$ & 3 & 86 & 60 & 25 & 6 & - & 180 \\
\hline & $2015-2017$ & 8 & 88 & 57 & 30 & 8 & - & 191 \\
\hline On average & 2009-2017 & 4 & 85 & 60 & 25 & 6 & - & 180 \\
\hline Vegetable & 2009-2011 & 1 & 34 & 33 & 50 & 47 & \multirow{4}{*}{$\begin{array}{r}-2 \\
4 \\
2\end{array}$} & 165 \\
\hline \multirow[t]{2}{*}{ crops } & $2012-2014$ & 1 & 34 & 33 & 46 & 49 & & 165 \\
\hline & $2015-2017$ & 2 & 30 & 32 & 41 & 52 & & 161 \\
\hline On average & 2009-2017 & 2 & 30 & 33 & 45 & 49 & & 164 \\
\hline \multirow[t]{3}{*}{ Mixed } & 2009-2011 & 22 & 766 & 744 & 524 & 171 & \multirow{4}{*}{$\begin{array}{r}1 \\
-1 \\
1\end{array}$} & 2228 \\
\hline & $2012-2014$ & 39 & 681 & 321 & 459 & 188 & & 1988 \\
\hline & $2015-2017$ & 44 & 564 & 505 & 417 & 192 & & 1723 \\
\hline On average & $2009-2017$ & 39 & 674 & 626 & 467 & 184 & & 1991 \\
\hline
\end{tabular}

Source: Polish FADN 2009-2017.

Table 3

Payment for employed labour in agricultural holdings by types of farming in the national economy and interest rate on long-term bonds in 2009-2017

\begin{tabular}{lccc}
\hline \multirow{2}{*}{\multicolumn{1}{c}{ Farm types }} & \multicolumn{2}{c}{$\begin{array}{c}\text { Classes of farms by the level of income } \\
\text { from farm (PLN/h) in periods }\end{array}$} \\
\cline { 2 - 4 } & $2009-2011$ & $2012-2014$ & $2015-2017$ \\
\hline Field crops & 8.47 & 9.42 & 13.48 \\
Dairy cattle & 8.97 & 10.19 & 13.18 \\
Permanent (orchard) crops & 8.19 & 8.62 & 11.98 \\
Vegetable crops & 8.54 & 9.39 & 12.05 \\
Mixed & 8.13 & 9.37 & 13.02 \\
Payment for work in the national economy (PLN/h) & 11.81 & 13.63 & 15.38 \\
Interest rate on long-term bonds (\%) & 5.90 & 5.20 & 2.60 \\
\hline
\end{tabular}

Source: own research. 
The interest rate on 10-year bonds was also determined as the basis for determining the cost of using equity, being the basis for calculating the competitiveness index. The analysis of the costs of employed labour in agriculture indicates that in 2009-2017:

- in individual three-year periods, the lowest costs of employed labour were observed in orchard farms and were lower than the highest costs in the case of dairy farms by $9 \%, 15 \%$ and $9 \%$, respectively;

- in the analysed periods, there was an increase in the cost of employed labour in the range of $40 \%$ to $60 \%$; the largest in mixed farms and with field crops $(60 \%)$, while smallest in vegetable farms (40\%). Payment for work in the national economy increased $30 \%$ in this period;

- the difference between payment for employed labour in agriculture and payment for work in the national economy decreased. In the first three years (2009-2011), payment for employed labour in the studied types of farms was on average $28 \%$ lower, and in the last three years (2015-2017) 17\% lower than payment in the national economy;

- the interest rate on 10 -year bonds also decreased from $5.9 \%$ to $2.6 \%$, i.e. by 3.3 percentage points.

The following indicators were included in the analysis of separated classes of farms: economic size of the farm (thous. SO), farm area (ha of UAA), share of leased land (\%), labour input (AWU/farm), share of employed labour, technical equipment of labour (value of assets in thous. EUR/AWU), average payment for employed labour on farms (PLN/h), income from farm per family work unit (FWU) $(\mathrm{PLN} / \mathrm{h})$, income parity indicator $(\mathrm{A})$, income parity indicator $(\mathrm{B})$, competitiveness index $(\mathrm{CI}) .^{5}$

\section{Adjustment processes on farms with field crops}

The numbers characterising changes that occurred on farms with field crops are presented in Tables 4 and 5. They allow the following statements:

- in the analysed periods, the structure of farms changed: the share of auxiliary farms increased from $17.7 \%$ to $32.2 \%$, of transitional farms decreased from $9.1 \%$ to $3.9 \%$. The share of developmental farms remained at a stable level of about $69.0 \%$;

- the studied farms differed in economic size. The average economic size of auxiliary farms was EUR 24.7 thous. of SO and showed a downward trend in subsequent periods. The average size of transitional farms was EUR 28.6 thous. of SO. It showed an upward trend and was $16 \%$ larger than that of auxiliary farms. The average economic size of developmental farms was EUR 77.3 thous. of SO, it showed an upward trend and was about twice as large as that of auxiliary farms;

\footnotetext{
${ }^{5}$ The competitiveness index (CI) was calculated as the quotient of income from farm and estimated costs of family work (according to the average net remuneration for work in the national economy), own land (according to the rate of lease rent) and equity (according to the interest rate of ten-year bonds) (Kleinhanss, 2015).
} 
- the area of farms was related to the economic size. Their average area in subsequent groups was $23.5,27.4$ and 75.8 ha of UAA, respectively, and was stable;

- farms of all groups used leased land whose average share in subsequent groups increased from $23.7 \%$ to $34.9 \%$;

- total labour input expressed in AWU per farm on auxiliary and transitional farms was similar and amounted to 1.68 AWU on average, while on developmental farms it was $19 \%$ higher ( 2 AWU);

- the studied farms used employed labour. Its share in total outlays of auxiliary and transitional farms was similar and amounted to $7.5 \%$ and $7.3 \%$, respectively, while in developmental farms it was $19.1 \%$;

- the analysed farms differed in technical equipment of labour. On auxiliary and transitional farms it was similar and amounted to 193.6 and 204.9 thous. EUR/ UAA, respectively. However, on developmental farms it was more than twice as high and amounted to 434 thous. EUR/AWU;

- payment for employed labour showed an increasing tendency in subsequent periods and groups. It was the lowest on auxiliary farms, where it amounted to $9.44 \mathrm{PLN} / \mathrm{h}$ on average, on transitional farms it was about $6 \%$ higher, and on developmental farms it amounted to $10.6 \mathrm{PLN} / \mathrm{h}$ and was by $12.3 \%$ higher than on auxiliary farms;

- income from farm per hour of family work varied considerably. It was the lowest on auxiliary farms where it amounted to $5.3 \mathrm{PLN} / \mathrm{h}$ on average, and on transitional farms $12 \mathrm{PLN} / \mathrm{h}$. So it was 126\% higher than in the previous group. It was definitely higher on developmental farms where it amounted to $48.5 \mathrm{PLN} / \mathrm{h}$. In all groups it showed a growing tendency in subsequent periods;

- the parity A and B indicators on auxiliary farms were $50.9 \%$ and $38.6 \%$, respectively. This means that income from farm per hour of family work was significantly lower than parity income, by 49.1 and 61.3 percentage points, respectively. In the case of transitional farms, this income was higher than payment for employed labour in agriculture, on average by $16 \%$, but lower than payment for work in the national economy by $12.7 \%$ on average. Income parity A and B indicators on developmental farms amounted to $360 \%$ and $324.2 \%$, respectively;

- auxiliary and transitional farms did not have the ability to compete. Their competitiveness index was 0.35 and 0.74 , respectively. Only developmental farms showed this ability, with the competitiveness index amounting to 1.77 on average. 
Features of farms with field crops in 2009-2017

Table 4

\begin{tabular}{|c|c|c|c|}
\hline \multirow{2}{*}{ Periods } & \multicolumn{3}{|c|}{ Classes of farms } \\
\hline & Auxiliary & Transitional & Developmental \\
\hline \multicolumn{4}{|c|}{ Number/Structure of farms (\%) } \\
\hline $2009-2011$ & $226 / 17.7$ & $116 / 9.1$ & $933 / 72.2$ \\
\hline $2012-2014$ & $238 / 16.6$ & $178 / 12.5$ & $1011 / 70.8$ \\
\hline $2015-2017$ & $538 / 32.2$ & $66 / 3.9$ & $1066 / 63.9$ \\
\hline \multicolumn{4}{|c|}{ Economic size of farms (thou. EUR SO) } \\
\hline 2009-2011 & 28.2 & 26.4 & 74.6 \\
\hline $2012-2014$ & 20.8 & 28.5 & 77.0 \\
\hline $2015-2017$ & 25.0 & 30.8 & 80.4 \\
\hline \multicolumn{4}{|c|}{ Utilised agricultural area (ha) } \\
\hline 2009-2011 & 26.1 & 25.6 & 73.5 \\
\hline $2012-2014$ & 20.6 & 25.2 & 76.6 \\
\hline $2015-2017$ & 23.9 & 31.5 & 77.3 \\
\hline \multicolumn{4}{|c|}{ The share of leased area $(\%)$} \\
\hline 2009-2011 & 24.9 & 38.3 & 37.9 \\
\hline 2012-2014 & 21.4 & 27.0 & 34.7 \\
\hline $2015-2017$ & 24.7 & 26.6 & 32.1 \\
\hline \multicolumn{4}{|c|}{ Labour input (AWU/farm) } \\
\hline 2009-2011 & 1.74 & 1.68 & 2.06 \\
\hline 2012-2014 & 1.68 & 1.85 & 1.99 \\
\hline $2015-2017$ & 1.62 & 1.50 & 1.94 \\
\hline \multicolumn{4}{|c|}{ Share of employed labour (\%) } \\
\hline $2009-2011$ & 9.8 & 6.0 & 19.4 \\
\hline $2012-2014$ & 6.0 & 11.4 & 20.1 \\
\hline $2015-2017$ & 6.8 & 4.6 & 18.0 \\
\hline \multicolumn{4}{|c|}{ Technical equipment of labour (thous. EUR/AWU) } \\
\hline 2009-2011 & 205.6 & 166.5 & 377.6 \\
\hline $2012-2014$ & 175.0 & 179.1 & 452.1 \\
\hline $2015-2017$ & 200.3 & 269.2 & 472.5 \\
\hline
\end{tabular}

Source: own research. 
Payment for employed labour, income from farm, income parity and competitiveness index on farms with field crops in 2009-2017

\begin{tabular}{|c|c|c|c|}
\hline \multirow{2}{*}{ Periods } & \multicolumn{3}{|c|}{ Classes of farms } \\
\hline & Auxiliary & Transitional & Developmental \\
\hline \multicolumn{4}{|c|}{ Payment for employed labour on farms (PLN/h) } \\
\hline 2009-2011 & 7.94 & 7.34 & 8.55 \\
\hline $2012-2014$ & 8.10 & 8.24 & 9.62 \\
\hline $2015-2017$ & 12.28 & 14.37 & 13.68 \\
\hline \multicolumn{4}{|c|}{ Income from farm (PLN/h) } \\
\hline $2009-2011$ & 4.49 & 10.13 & 43.40 \\
\hline 2012-2014 & 4.63 & 11.38 & 53.40 \\
\hline $2015-2017$ & 6.80 & 14.48 & 48.62 \\
\hline \multicolumn{4}{|c|}{ Indicator of parity A (\%) } \\
\hline 2009-2011 & 53.0 & 119.6 & 321.9 \\
\hline $2012-2014$ & 49.1 & 120.8 & 396.1 \\
\hline $2015-2017$ & 50.5 & 107.4 & 360.7 \\
\hline \multicolumn{4}{|c|}{ Indicator of parity B (\%) } \\
\hline $2009-2011$ & 38.0 & 85.8 & 282.2 \\
\hline $2012-2014$ & 34.0 & 83.5 & 347.2 \\
\hline $2015-2017$ & 44.2 & 94.1 & 316.1 \\
\hline \multicolumn{4}{|c|}{ Competitiveness Index } \\
\hline $2009-2011$ & 0.29 & 0.76 & 1.72 \\
\hline $2012-2014$ & 0.33 & 0.77 & 1.84 \\
\hline $2015-2017$ & 0.42 & 0.70 & 1.75 \\
\hline
\end{tabular}

Source: own research.

\section{Adjustment processes on farms specialising in dairy cattle}

The numbers characterising changes in the organisation of dairy farms in the analysed periods are presented in Tables 6 and 7. Based on them, the following statements can be made:

- in the studied periods, the structure of the analysed dairy farms was quite stable. The average share of auxiliary farms was about $24.5 \%$, showing a slight upward trend. The share of transitional farms was definitely lower, which was $10.3 \%$ on average, with a downward trend: from $12.9 \%$ to $6.4 \%$. The share of developmental farms was by far the highest and stable, and amounted to $65.2 \%$ on average; 
Features of farms specialising in dairy cattle farming in 2009-2017

Table 6

\begin{tabular}{|c|c|c|c|}
\hline \multirow{2}{*}{ Periods } & \multicolumn{3}{|c|}{ Classes of farms } \\
\hline & Auxiliary & Transitional & Developmental \\
\hline \multicolumn{4}{|c|}{ Number/structure of farms } \\
\hline 2009-2011 & $279 / 24.7$ & $145 / 12.9$ & $703 / 62.4$ \\
\hline 2012-2014 & $261 / 22.4$ & $136 / 11.7$ & $768 / 65.9$ \\
\hline $2015-2017$ & $305 / 26.3$ & $74 / 6.4$ & $782 / 67.3$ \\
\hline \multicolumn{4}{|c|}{ Economic size of farms (thou. EUR SO) } \\
\hline 2009-2011 & 29.3 & 37.3 & 67.2 \\
\hline 2012-2014 & 29.8 & 34.4 & 74.5 \\
\hline $2015-2017$ & 33.0 & 40.6 & 78.7 \\
\hline \multicolumn{4}{|c|}{ Utilised agricultural area (ha) } \\
\hline 2009-2011 & 18.2 & 22.6 & 36.7 \\
\hline $2012-2014$ & 18.8 & 21.0 & 38.6 \\
\hline $2015-2017$ & 20.6 & 24.6 & 40.3 \\
\hline \multicolumn{4}{|c|}{ The share of leased area $(\%)$} \\
\hline 2009-2011 & 25.8 & 28.3 & 30.0 \\
\hline 2012-2014 & 26.6 & 24.3 & 31.3 \\
\hline $2015-2017$ & 27.2 & 24.4 & 31.8 \\
\hline \multicolumn{4}{|c|}{ Labour input (AWU/holding) } \\
\hline 2009-2011 & 1.87 & 1.97 & 2.07 \\
\hline 2012-2014 & 1.87 & 1.94 & 2.12 \\
\hline $2015-2017$ & 1.87 & 2.00 & 2.10 \\
\hline \multicolumn{4}{|c|}{ Share of employed labour $(\%)$} \\
\hline 2009-2011 & 1.0 & 1.0 & 6.8 \\
\hline 2012-2014 & 1.0 & 1.0 & 7.5 \\
\hline 2015-2017 & 2.1 & 1.5 & 6.2 \\
\hline \multicolumn{4}{|c|}{ Technical equipment of labour (thous. EUR/AWU) } \\
\hline 2009-2011 & 184.1 & 216.7 & 379.2 \\
\hline $2012-2014$ & 196.5 & 210.5 & 440.2 \\
\hline $2015-2017$ & 199.7 & 216.5 & 473.4 \\
\hline
\end{tabular}

Source: own research.

- the economic size of farms showed an upward trend in all groups and periods. The average size of auxiliary farms was EUR 30.7 thous. of SO, while of transitional farms EUR 37.4 thous. of SO and was by $21.8 \%$ higher. The average economic size of developmental farms was EUR 73.5 thous. of SO and was by $139 \%$ higher than that of auxiliary farms; 
- the area of the dairy farms studied was related to the economic size, but not as strongly as on farms with field crops. The average area of auxiliary dairy farms was 19.2 ha, and of transitional farms 22.7 ha of UAA, showing a growing tendency in subsequent periods. The average area of developmental dairy farms was 38.5 ha of UAA, with an increasing tendency. It was two times larger than the size of auxiliary farms;

- the analysed farms used leased land but to a fairly moderate extent. Its share was in the range of $25.7 \%$ (transitional) to $31 \%$ (developmental);

- labour inputs were stable over time and not very diverse between groups: on developmental farms they amounted to 2.1 AWU and were by $12 \%$ higher than on auxiliary farms. Auxiliary and transitional dairy farms made little use of employed labour (1.25\%). The share of employed labour on developmental farms was slightly higher, at $6.8 \%$;

- there were distinct differences in technical equipment of labour. On developmental farms, the value of assets per AWU was on average EUR 431 thous. and was twice as high as in both other groups;

Table 7

Payment for employed labour, income from farm, income parity and competitiveness index on farms with dairy cattle in 2009-2017

\begin{tabular}{|c|c|c|c|}
\hline \multirow{2}{*}{ Periods } & \multicolumn{3}{|c|}{ Classes of farms } \\
\hline & Auxiliary & Transitional & Developmental \\
\hline \multicolumn{4}{|c|}{ Payment for employed labour on farms (PLN/h) } \\
\hline $2009-2011$ & 9.01 & 7.68 & 8.93 \\
\hline 2012-2014 & 9.16 & 9.95 & 10.25 \\
\hline $2015-2017$ & 13.07 & 12.19 & 13.22 \\
\hline \multicolumn{4}{|c|}{ Income from farm (PLN/h) } \\
\hline $2009-2011$ & 5.61 & 10.34 & 28.61 \\
\hline 2012-2014 & 6.09 & 11.95 & 35.41 \\
\hline $2015-2017$ & 8.08 & 14.18 & 39.16 \\
\hline \multicolumn{4}{|c|}{ Indicator of parity A $(\%)$} \\
\hline $2009-2011$ & 62.5 & 115.3 & 318.9 \\
\hline 2012-2014 & 59.8 & 117.3 & 347.5 \\
\hline $2015-2017$ & 61.3 & 107.6 & 297.1 \\
\hline \multicolumn{4}{|c|}{ Indicator of parity B (\%) } \\
\hline $2009-2011$ & 47.50 & 87.5 & 242.2 \\
\hline 2012-2014 & 44.70 & 87.7 & 250.8 \\
\hline $2015-2017$ & 52.50 & 92.2 & 254.6 \\
\hline \multicolumn{4}{|c|}{ Competitiveness Index } \\
\hline $2009-2011$ & 0.38 & 0.71 & 1.30 \\
\hline 2012-2014 & 0.41 & 0.72 & 1.44 \\
\hline $2015-2017$ & 0.52 & 0.90 & 1.80 \\
\hline
\end{tabular}

Source: own research. 
- payment for employed labour showed a growing tendency in subsequent periods. The highest increase occurred in the case of transitional farms in which it was $58.7 \%$, while in developmental farms $48 \%$, and in auxiliary farms $45 \%$. The diversification of payment between the groups was small. The difference between the extreme groups was $8.6 \%$;

- income from farm per hour of family work (FWU) increased in subsequent periods, in the range of $36.9 \%$ (developmental farms) to $47 \%$ (auxiliary farms). There were distinct differences between the groups. On auxiliary farms, the income was on average 6.6 PLN/h, on temporary farms 12.1 PLN/h and on developmental farms 34.4 PLN/ha;

- the indicator of parity A in the periods was quite stable. It increased in subsequent groups. On average, on auxiliary farms it was $61.2 \%$, on transitional farms $113.4 \%$, and on developmental farms $321.2 \%$. The indicator of parity B was lower in subsequent groups. On auxiliary farms it was $48 \%$, on transitional farms $89.1 \%$, and on developmental farms $249.2 \%$;

- the value of the competitiveness index (CI) shows that auxiliary and transitional farms did not have the ability to compete. Their average value of the CI was 0.44 and 0.78 , respectively, with an upward trend in subsequent periods. Developmental farms showed the ability to compete. The average value of the CI was 1.51 , showing an upward trend, from 1.30 to 1.80 .

\section{Adjustment processes on farms with permanent crops}

The numbers characterising changes occurring on farms with permanent crops are presented in Tables 8 and 9. They allow the following statements:

- the structure of the analysed orchard farms is polarised. Extreme groups occupy the dominant position. The average share of auxiliary farms was $39.5 \%$ and developmental farms $47.6 \%$. There was an upward trend in the group of auxiliary farms, from $37.0 \%$ to $46.1 \%$, and a downward trend in the group of developmental farms, from $50 \%$ to $44 \%$. The average share of transitional farms was $12.8 \%$, with a downward trend in subsequent periods, from $13.0 \%$ to $9.9 \%$;

- the economic size of auxiliary and transitional farms was similar and amounted to EUR 25.3 and 26.9 thous. of SO, respectively, showing a downward trend in subsequent periods. The average economic size of developmental farms amounted to EUR 42.7 thous. of SO. It was stable in subsequent periods and by about $64 \%$ larger than that of farms from other groups;

- similar trends occurred in the UAA which on auxiliary and transitional farms amounted to 11 ha on average, while in developmental farms - 17.8 ha of UAA, and was by about $73 \%$ larger than in other groups. The area of farms in all groups was stable in subsequent periods;

- even though the analysed orchard farms used leased land, it was to a small extent - from $6.7 \%$ on auxiliary farms to $12.1 \%$ on transitional farms;

- labour input on auxiliary and transitional farms was similar, amounted to 2.3 and 2.5 AWU per farm, respectively, and showed a downward trend in subse- 
quent periods. Labour input on developmental farms was 3.4 AWU on average and showed an upward trend. Farms of all groups used employed labour. Its share in total labour input of auxiliary and transitional farms was similar and amounted to $30.8 \%$ and $28.1 \%$, respectively. On developmental farms it was definitely higher and quite stable, amounting to $52.3 \%$ on average;

- technical equipment of labour on auxiliary and transitional farms was similar and amounted to 187.9 and 172.2 thous. EUR/AWU, respectively, however on developmental farms it was by about 35\% higher. In the first two groups of farms, there was a downward trend, while in developmental farms an upward trend;

Table 8

Features of farms with permanent (orchard) crops in 2009-2017

\begin{tabular}{|c|c|c|c|}
\hline \multirow{2}{*}{ Periods } & \multicolumn{3}{|c|}{ Classes of farms } \\
\hline & Auxiliary & Transitional & Developmental \\
\hline \multicolumn{4}{|c|}{ Number/Structure of farms (\%) } \\
\hline $2009-2011$ & $63 / 37.0$ & $22 / 13.0$ & $85 / 50.0$ \\
\hline 2012-2014 & $64 / 35.5$ & $28 / 15.6$ & $88 / 48.9$ \\
\hline $2015-2017$ & $88 / 46.1$ & $19 / 9.9$ & $84 / 44.0$ \\
\hline \multicolumn{4}{|c|}{ Economic size of farms (thou. EUR SO) } \\
\hline $2009-2011$ & 26.8 & 27.0 & 41.6 \\
\hline 2012-2014 & 24.7 & 28.0 & 41.8 \\
\hline $2015-2017$ & 24.3 & 25.8 & 44.8 \\
\hline \multicolumn{4}{|c|}{ Utilised agricultural area (ha) } \\
\hline $2009-2011$ & 11.5 & 11.4 & 17.6 \\
\hline 2012-2014 & 10.7 & 11.9 & 17.4 \\
\hline 2015-2017 & 10.7 & 9.8 & 18.3 \\
\hline \multicolumn{4}{|c|}{ The share of leased area $(\%)$} \\
\hline $2009-2011$ & 7.0 & 11.1 & 15.3 \\
\hline 2012-2014 & 6.5 & 10.9 & 6.3 \\
\hline $2015-2017$ & 6.7 & 14.3 & 7.1 \\
\hline \multicolumn{4}{|c|}{ Labour input (AWU/farm) } \\
\hline $2009-2011$ & 2.52 & 2.65 & 3.08 \\
\hline 2012-2014 & 2.36 & 2.77 & 3.65 \\
\hline $2015-2017$ & 1.89 & 2.14 & 3.35 \\
\hline \multicolumn{4}{|c|}{ Share of employed labour $(\%)$} \\
\hline $2009-2011$ & 36.9 & 28.7 & 50.6 \\
\hline 2012-2014 & 34.3 & 31.0 & 56.4 \\
\hline $2015-2017$ & 21.2 & 25.7 & 49.9 \\
\hline \multicolumn{4}{|c|}{ Technical equipment of labour (thous. EUR/AWU) } \\
\hline $2009-2011$ & 197.0 & 196.7 & 222.5 \\
\hline $2012-2014$ & 189.6 & 142.1 & 230.9 \\
\hline $2015-2017$ & 177.0 & 177.8 & 277.9 \\
\hline
\end{tabular}

Source: own research. 
Table 9

Payment for employed labour, income from farm, income parity and competitiveness index on farms with permanent crops in 2009-2017

\begin{tabular}{|c|c|c|c|}
\hline \multirow{2}{*}{ Periods } & \multicolumn{3}{|c|}{ Classes of farms } \\
\hline & Auxiliary & Transitional & Developmental \\
\hline \multicolumn{4}{|c|}{ Payment for employed labour on farms (PLN/h) } \\
\hline $2009-2011$ & 7.80 & 8.46 & 8.33 \\
\hline $2012-2014$ & 8.51 & 8.32 & 8.64 \\
\hline $2015-2017$ & 12.06 & 11.36 & 12.0 \\
\hline \multicolumn{4}{|c|}{ Income from farm (PLN/h) } \\
\hline $2009-2011$ & 2.0 & 10.12 & 32.07 \\
\hline $2012-2014$ & 3.2 & 11.10 & 35.55 \\
\hline $2015-2017$ & 5.0 & 13.29 & 42.40 \\
\hline \multicolumn{4}{|c|}{ Indicator of parity $\mathrm{A}(\%)$} \\
\hline $2009-2011$ & 24.4 & 123.6 & 391.6 \\
\hline 2012-2014 & 37.1 & 128.7 & 412.4 \\
\hline $2015-2017$ & 41.7 & 110.9 & 353.9 \\
\hline \multicolumn{4}{|c|}{ Indicator of parity B (\%) } \\
\hline $2009-2011$ & 16.9 & 85.7 & 271.5 \\
\hline $2012-2014$ & 23.5 & 81.4 & 260.8 \\
\hline $2015-2017$ & 32.5 & 86.4 & 275.7 \\
\hline \multicolumn{4}{|c|}{ Competitiveness Index } \\
\hline $2009-2011$ & 0.11 & 0.54 & 1.38 \\
\hline $2012-2014$ & 0.18 & 0.80 & 2.40 \\
\hline $2015-2017$ & 0.40 & 0.89 & 1.98 \\
\hline
\end{tabular}

Source: own research.

- the degree of diversification of payment for employed labour was low, ranging from PLN 9.4/h on transition farms to 9.7 PLN/h on developmental farms. There was an upward trend in all groups in subsequent periods, the largest on auxiliary farms in which this payment increased $54.6 \%$, and the lowest on transitional farms in which it was $34.3 \%$;

- income from farm per hour of family work varied considerably. It was the lowest on auxiliary farms with 3.4 PLN/h on average, and the highest on developmental farms with $36.7 \mathrm{PLN} / \mathrm{h}$. In all groups, income increased in subsequent periods: the most on auxiliary farms in which it increased $150 \%$, while on transition and development $31.3 \%$ and $32.2 \%$, respectively. Income parity indicators varied strongly between groups of farms. On auxiliary farms, the values of indicators A and B were $34.4 \%$ and $24.3 \%$, respectively. Transitional farms exceeded the parity A income, but did not reach the level of parity B income, whose indicator was $84.5 \%$. Developmental farms received income much higher than parity A and B income; 
- similarly to the previous types of farming, auxiliary and transitional farms do not have the ability to compete. Their competitiveness index (CI) was 0.23 and 0.74 , respectively, with an upward trend in subsequent periods. The ability to compete was demonstrated by developmental farms.

\section{Adjustment processes on farms with vegetable crops}

The numbers characterising changes occurring on farms with vegetable crops are presented in Tables 10 and 11. They allow the following statements:

- the structure of these farms was dominated by developmental farms - their average share was $53.6 \%$, and auxiliary farms with $37.3 \%$ share. The share of transitional farms was $9.2 \%$ on average. The structure of farms was stable in subsequent periods;

- the economic size of auxiliary and transitional farms was similar and amounted to 51.6 and 65.6 thous. EUR of SO, respectively. On auxiliary farms it was stable in subsequent periods, while on transitional farms it increased. The growth rate was $30.5 \%$. The economic size of developmental farms was on average EUR 129 thous. of SO, showing an upward trend. The growth rate was $34.8 \%$. It was about twice as large as on other farms;

- the area of auxiliary and transitional farms was similar, and amounted to 5.0 and 5.6 ha of UAA, respectively. The area of developmental farms was definitely larger - about 50\%. It also increased in subsequent periods from 7 to 9 ha of UAA;

- the analysed vegetable farms used leased land. Its share in auxiliary and transitional farms was small and amounted to $8.3 \%$ and $6.5 \%$, respectively. On developmental farms it was much higher, it amounted to $25.7 \%$, showing an upward trend from $23.9 \%$ to $31.1 \%$;

- total labour input varied - it was lower on auxiliary and transitional farms in which it amounted to 2.3 and 2.8 AWU, respectively. On developmental farms it was about two times larger. It amounted to 5.2 AWU;

- all the farms used employed labour. Its share in total input of auxiliary and transitional farms and amounted to $22.6 \%$ and $29.2 \%$, respectively, while on developmental farms $66 \%$, showing an upward trend from $62.1 \%$ to $68.7 \%$;

- the degree of diversification in terms of technical equipment of labour was lower than in the previously discussed types of farms. On developmental farms, the rate of technical equipment of labour amounted to 207 thous. EUR/ AWU and was $62.6 \%$ and $34.7 \%$ higher, respectively, than on auxiliary and transitional farms; 
Features of farms with vegetable crops in 2009-2017

Table 10

\begin{tabular}{|c|c|c|c|}
\hline \multirow{2}{*}{ Periods } & \multicolumn{3}{|c|}{ Classes of farms } \\
\hline & Auxiliary & Transitional & Developmental \\
\hline \multicolumn{4}{|c|}{ Number/structure of farms $(\%)$} \\
\hline $2009-2011$ & $64 / 38.7$ & $15 / 9.1$ & $86 / 52.1$ \\
\hline $2012-2014$ & $58 / 35.1$ & $15 / 9.1$ & 9255.8 \\
\hline $2015-2017$ & $61 / 37.9$ & $15 / 9.3$ & $85 / 52.8$ \\
\hline \multicolumn{4}{|c|}{ Economic size of farms (thou. EUR SO) } \\
\hline $2009-2011$ & 53.0 & 59.0 & 110.0 \\
\hline 2012-2014 & 47.3 & 60.9 & 128.7 \\
\hline $2015-2017$ & 54.4 & 77. & 148.3 \\
\hline \multicolumn{4}{|c|}{ Utilised agricultural area (ha) } \\
\hline $2009-2011$ & 5.4 & 5.5 & 7.0 \\
\hline 2012-2014 & 5.3 & 3.9 & 7.7 \\
\hline $2015-2017$ & 4.2 & 7.4 & 9.0 \\
\hline \multicolumn{4}{|c|}{ The share of leased area $(\%)$} \\
\hline $2009-2011$ & 7.4 & 12.7 & 23.9 \\
\hline 2012-2014 & 9.4 & 1.5 & 22.1 \\
\hline $2015-2017$ & 8.0 & 5.4 & 31.1 \\
\hline \multicolumn{4}{|c|}{ Labour input (AWU/farm) } \\
\hline $2009-2011$ & 2.64 & 3.10 & 4.57 \\
\hline $2012-2014$ & 2.16 & 2.91 & 5.28 \\
\hline $2015-2017$ & 2.15 & 2.26 & 5.68 \\
\hline \multicolumn{4}{|c|}{ Share of employed labour (\%) } \\
\hline $2009-2011$ & 30.3 & 38.7 & 62.1 \\
\hline 2012-2014 & 17.1 & 33.0 & 67.0 \\
\hline $2015-2017$ & 20.5 & 15.9 & 68.7 \\
\hline \multicolumn{4}{|c|}{ Technical equipment of labour (thous. EUR/AWU) } \\
\hline $2009-2011$ & 130.9 & 133.4 & 209.6 \\
\hline $2012-2014$ & 117.9 & 173.9 & 197.0 \\
\hline 2015-2017 & 133.0 & 153.8 & 214.5 \\
\hline
\end{tabular}

Source: own research.

- the degree of diversification of payment for employed labour was small. It was always ranging from 9.4 to $10 \mathrm{PLN} / \mathrm{h}$. In all groups it showed a growing tendency in subsequent periods. It increased the most considerably in auxiliary farms $-51 \%$, and $40 \%$ in developmental farms;

- the degree of diversification of income from farm per hour of family work was large. On auxiliary farms it was 4.2 PLN/h on average, while on developmental farms $45.1 \mathrm{PLN} / \mathrm{h}$. It showed an upward trend in subsequent periods. The income parity $\mathrm{A}$ and $\mathrm{B}$ indicator on auxiliary farms was low and amounted to $42.1 \%$ and $30.9 \%$, respectively. On transition farms, the A indicator was $117.4 \%$ 
and $\mathrm{B}$ indicator $85.7 \%$. The parity A and B indicators on developmental farms were high, reaching $453.1 \%$ and $331.8 \%$, respectively;

- values of competitiveness indices indicate that auxiliary and transitional farms do not have the ability to compete. Such abilities are demonstrated by developmental farms in which in the first two periods the CI was 1.79 and 1.87, respectively, while in the third period 2.51, indicating full competitiveness of this group of farms.

Table 11

Payment for employed labour, income from farm, income parity and competitiveness index on farms with vegetable crops in 2009-2017

\begin{tabular}{|c|c|c|c|}
\hline \multirow{2}{*}{ Periods } & \multicolumn{3}{|c|}{ Classes of farms } \\
\hline & Auxiliary & Transitional & Developmental \\
\hline \multicolumn{4}{|c|}{ Payment for employed labour on farms (PLN/h) } \\
\hline $2009-2011$ & 8.03 & 9.35 & 8.59 \\
\hline $2012-2014$ & 8.71 & 7.99 & 9.50 \\
\hline $2015-2017$ & 12.12 & 11.00 & 12.05 \\
\hline \multicolumn{4}{|c|}{ Income from farm (PLN/h) } \\
\hline $2009-2011$ & 3.66 & 10.16 & 40.51 \\
\hline 2012-2014 & 3.70 & 11.44 & 43.10 \\
\hline $2015-2017$ & 5.30 & 13.43 & 51.70 \\
\hline \multicolumn{4}{|c|}{ Indicator of parity A (\%) } \\
\hline $2009-2011$ & 42.8 & 119.0 & 474.3 \\
\hline $2012-2014$ & 39.4 & 121.8 & 456.0 \\
\hline $2015-2017$ & 44.0 & 111.4 & 429.0 \\
\hline \multicolumn{4}{|c|}{ Indicator of parity B $(\%)$} \\
\hline $2009-2011$ & 31.0 & 86.0 & 343.0 \\
\hline $2012-2014$ & 27.1 & 83.9 & 316.2 \\
\hline 2015-2017 & 34.5 & 87.3 & 336.1 \\
\hline \multicolumn{4}{|c|}{ Competitiveness Index } \\
\hline $2009-2011$ & 0.24 & 0.62 & 1.79 \\
\hline $2012-2014$ & 0.28 & 0.74 & 1.87 \\
\hline $2015-2017$ & 0.37 & 0.97 & 2.51 \\
\hline
\end{tabular}

Source: own research.

\section{Adjustment processes on farms with mixed production}

The numbers characterising changes on "mixed" type of farms are presented in Tables 12 and 13. They allow the following statements to be made:

- the structure of mixed farms was dominated by auxiliary and developmental farms. Their average share was $43.1 \%$ and $44 \%$, respectively. In the analysed period, the share of auxiliary farms showed an increasing tendency, while the share of developmental farms a decreasing tendency. The share of transitional farms was $13 \%$. It showed a downward trend from $16.3 \%$ to $7.2 \%$; 
Features of mixed-production farms in 2009-2017

Table 12

\begin{tabular}{|c|c|c|c|}
\hline \multirow{2}{*}{ Periods } & \multicolumn{3}{|c|}{ Classes of farms } \\
\hline & Auxiliary & Transitional & Developmental \\
\hline \multicolumn{4}{|c|}{ Number/Structure of holdings $(\%)$} \\
\hline $2009-2011$ & $843 / 37.8$ & $363 / 16.3$ & $1022 / 45.8$ \\
\hline 2012-2014 & $812 / 40.9$ & $303 / 15.2$ & $873 / 43.9$ \\
\hline $2015-2017$ & $872 / 50.6$ & $125 / 7.2$ & $726 / 42.2$ \\
\hline \multicolumn{4}{|c|}{ Economic size of farms (thou. EUR SO) } \\
\hline $2009-2011$ & 22.1 & 34.8 & 68.6 \\
\hline $2012-2014$ & 23.4 & 36.4 & 73.9 \\
\hline $2015-2017$ & 26.8 & 39.3 & 81.1 \\
\hline \multicolumn{4}{|c|}{ Utilised agricultural area (ha) } \\
\hline $2009-2011$ & 15.5 & 21.6 & 41.0 \\
\hline 2012-2014 & 16.7 & 24.3 & 44.6 \\
\hline $2015-2017$ & 18.8 & 27.0 & 47.9 \\
\hline \multicolumn{4}{|c|}{ The share of leased area $(\%)$} \\
\hline $2009-2011$ & 19.4 & 22.2 & 28.0 \\
\hline $2012-2014$ & 21.0 & 26.7 & 29.1 \\
\hline $2015-2017$ & 22.3 & 24.8 & 29.6 \\
\hline \multicolumn{4}{|c|}{ Labour input (AWU/holding) } \\
\hline $2009-2011$ & 1.68 & 1.82 & 2.00 \\
\hline 2012-2014 & 1.71 & 1.79 & 2.04 \\
\hline $2015-2017$ & 1.68 & 1.68 & 1.96 \\
\hline \multicolumn{4}{|c|}{ Share of employed labour (\%) } \\
\hline $2009-2011$ & 1.8 & 2.7 & 11.5 \\
\hline $2012-2014$ & 2.9 & 2.2 & 11.8 \\
\hline $2015-2017$ & 1.2 & 1.2 & 7.1 \\
\hline \multicolumn{4}{|c|}{ Technical equipment of labour (thous. EUR/AWU) } \\
\hline $2009-2011$ & 154.9 & 187.1 & 322.4 \\
\hline $2012-2014$ & 164.2 & 203.0 & 371.8 \\
\hline $2015-2017$ & 173.6 & 222.6 & 395.2 \\
\hline
\end{tabular}

Source: own research.

- the analysed groups of farms differed in economic size. According to this criterion, auxiliary farms were the smallest. On average, their size was EUR 24.1 thous. of SO. Transitional farms were by about 53\% larger. Developmental farms were about three times larger than auxiliary farms. In all groups, the economic size of farms increased in subsequent periods;

- similar relationships occurred in the UAA. The area of auxiliary farms was $17 \mathrm{ha}$, while in the case of developmental farms 44.5 ha. It was over 2.6 times larger than that of auxiliary farms and 1.8 times larger than that of transitional farms. In all groups, the area of farms increased in subsequent periods; 
- farms of all groups used leased land whose share was ranging from 21\% (auxiliary farms) to $29 \%$ (developmental farms);

- the degree of diversification of labour input was not large, the area of variation did not exceed $20 \%$. On auxiliary farms it amounted to 1.69 , and on developmental farms $2 \mathrm{AWU} /$ farm. On transition and developmental farms there was a downward trend in subsequent periods;

- mixed farms used employed labour to a small extent. Its share in total labour input on auxiliary and transitional farms did not exceed $2 \%$. On developmental farms it was larger and amounted to $10 \%$;

- the analysed farms differed in technical equipment of labour. It was the smallest on auxiliary farms. Their value of assets amounted to 164.2 thous. EUR/ AWU. On transitional farms it was $24 \%$ larger and on developmental farms $121 \%$ larger. In all groups, the level of technical equipment of labour increased in subsequent years;

Table 13

Payment for employed labour, income from farm, income parity and competitiveness index on mixed-production farms in 2009-2017

\begin{tabular}{|c|c|c|c|}
\hline \multirow{2}{*}{ Periods } & \multicolumn{3}{|c|}{ Classes of farms } \\
\hline & Auxiliary & Transitional & Developmental \\
\hline \multicolumn{4}{|c|}{ Payment for employed labour on farms (PLN/h) } \\
\hline $2009-2011$ & 7.67 & 7.68 & 8.22 \\
\hline 2012-2014 & 8.48 & 8.87 & 9.60 \\
\hline $2015-2017$ & 12.47 & 11.69 & 13.15 \\
\hline \multicolumn{4}{|c|}{ Income from farm (PLN/h) } \\
\hline $2009-2011$ & 4.42 & 9.92 & 26.66 \\
\hline 2012-2014 & 4.57 & 11.25 & 32.10 \\
\hline $2015-2017$ & 6.47 & 14.11 & 32.75 \\
\hline \multicolumn{4}{|c|}{ Indicator of parity A (\%) } \\
\hline $2009-2011$ & 54.4 & 122.0 & 327.9 \\
\hline 2012-2014 & 48.7 & 120.0 & 342.6 \\
\hline $2015-2017$ & 49.7 & 108.4 & 251.5 \\
\hline \multicolumn{4}{|c|}{ Indicator of parity B (\%) } \\
\hline $2009-2011$ & 37.4 & 84.0 & 225.7 \\
\hline 2012-2014 & 33.5 & 82.5 & 235.5 \\
\hline $2015-2017$ & 42.07 & 91.7 & 212.9 \\
\hline \multicolumn{4}{|c|}{ Competitiveness Index } \\
\hline $2009-2011$ & 0.36 & 0.71 & 1.31 \\
\hline 2012-2014 & 0.35 & 0.73 & 1.37 \\
\hline $2015-2017$ & 0.42 & 0.89 & 1.48 \\
\hline
\end{tabular}

Source: own research. 
- the degree of diversification of payment for employed labour was small. The area of variation was about $8 \%$. The payment was the lowest in auxiliary farms, and the highest in developmental farms, where it amounted to $10.3 \mathrm{PLN} / \mathrm{h}$. There was an upward trend in all groups of farms. Labour costs increased the most, i.e. about $63 \%$, on auxiliary farms and the least on transitional farms - about $52 \%$;

- income from farm per hour of family work varied considerably. On average, on auxiliary farms it amounted to $5.15 \mathrm{PLN} / \mathrm{h}$. On transitional farms it was by $129 \%$ larger and on developmental farms by about $500 \%$ larger;

- income parity A and B indicators on auxiliary farms were low and amounted to $50.9 \%$ and $37.6 \%$, respectively. Transitional farms obtained parity A income, while the parity B income indicator was $86.1 \%$. Developmental farms received income three times exceeding parity A and twice parity B;

- auxiliary and transitional farms did not have the ability to compete. Their CI was 0.38 and 0.78 , respectively. Developmental farms, in which the CI was 1.39 , were able to compete. In all groups, the value of the CI showed an upward trend.

\section{Summary and conclusions}

In 2013, the Central Statistical Office in Poland changed the definition of an agricultural holding, and this precluded a retrospective analysis of the characterised phenomenon using mass statistics materials over long-term. Materials covering the period from 2013 to 2016 indicate that the number of farms decreased by $1.3 \%$. Therefore, the process of concentration of production on the functioning agricultural holdings could occur. The number of farms with mixed production but also specialised in vegetable and orchard production, raising of grazing animals and fed with concentrated feed (granivores) decreased, but at the same time the number of farms with field crops increased. As a result, the share of farms with specialised production increased to $75.7 \%$ (by 6.3 percentage points).

The structure of farms by types of farming also changed. Farms specialised in field crops maintained their dominant position. Despite a decrease, the share of farms with mixed production was still significant. The share of farms with grazing animals and orchard farms was relatively stable. The share of vegetable farms, farms with granivorous and unclassified farms was quite stable but low.

The research, using the results of monitoring of Polish FADN for 2007-2017, allows the following conclusions.

1. The share of auxiliary farms in individual types of farming was significant. It was ranging from $24.5 \%$ (farms with dairy cattle) to $43.1 \%$ (farms with mixed production). In all types it increased in subsequent periods. The average economic size of this group included the range from EUR 24.1 thous. of SO (mixed) to EUR 51.6 thous. of SO (vegetable). The average area of farms with field crops, dairy cattle and with mixed production was $23.5,19.2$ and 17 ha of UAA, respectively. The area of orchard and vegetable farms was 5 and 11 ha of UAA, respectively. Farms in this group did not achieve income parity in relation to 
payment for employed labour in agriculture (parity A) and payment in the national economy (parity B). The parity A indicator was in the range of $34.4 \%$ (orchard) to $61.29 \%$ (dairy cattle). The parity B indicator was lower, ranging from $24.3 \%$ (orchard) to $48 \%$ (dairy cattle). Auxiliary farms of all types did not have the ability to compete. The CI was low, in the range of 0.23 (orchard) to 0.47 (dairy cattle).

2. The share of transitional farms in individual types of farming was small, in the range of $8.5 \%$ (field crops) to $13 \%$ (mixed). There was a downward trend in all types, the strongest in the mixed production type, from $16 \%$ to $7.2 \%$. The average economic size of this group of farms was in the range of EUR 26.9 thous. of SO (orchard) to EUR 65.7 thous. of SO (vegetable) and was larger than that of auxiliary farms by $25 \%$ on average. The area of transitional farms: with field crops, dairy and mixed was similar, in the range of 22.7 ha (dairy) to 27.4 ha (with field crops). All farms in this group received income higher than parity A. The indicator of this parity was ranging from $113.4 \%$ (dairy) to $121.1 \%$ (orchard). However, they did not achieve income at the parity $\mathrm{B}$ level. The indicator was ranging from $84.5 \%$ (orchard) to $87.8 \%$ (field crops). Transitional farms did not have the ability to compete: the competitiveness index was in the range of 0.74 to 0.78 .

3. The share of developmental farms in individual types was diverse but significant, ranging from $44.4 \%$ (mixed) to $69 \%$ (with field crops). The average economic size of this group varied, ranging from EUR 42.7 thous. of SO (mixed) to EUR 129 thous. of SO (vegetable). The area also varied. The largest in this respect were farms with field crops, the area of which was 75.8 ha of UAA. Dairy and mixed farms used on average 38.5 and 44.5 ha of UAA. Orchard and vegetable farms were definitely smaller in terms of area, 17.8 and 7.8 ha of UAA, respectively. All farms in this group had an income exceeding parity A (more than three times) and B income (more than twice). Farms of this group showed the ability to compete in all periods, while orchard farms in 2012-2014 and vegetable farms in 2015-2017 were fully competitive. Their competitiveness index was 2.4 and 2.5 , respectively.

4. Application of the criterion of the level of income from farm per unit of work of a farmer (and farmer's family members) compared to payment for employed labour in agriculture and wages in the national economy to the classification of farms in terms of their nature is justified. The division of farms according to this criterion into auxiliary, transitional and developmental allows for an in-depth analysis from the point of view of agricultural policy. The area criterion does not lose its significance from the point of view of organisation of farms, however it is of little use from an economic and social point of view. 


\section{References}

Bocian, M., Osuch, D., Smolik, A. (2018). Parametry techniczno-ekonomiczne wedtug grup gospodarstw rolnych uczestniczacych w Polskim FADN w 2016 roku. Warszawa: IERiGZ̈-PIB.

Brinkmann, T. (1992). Die oekonomik des landwirtschaftlichen Betriebes. Grundriss der Sozialoekonomik. Tübingen.

Czyżewski, B. (2017). Kierat rynkowy w europejskim rolnictwie. Warszawa: Wydawnictwo PWN.

Dudek, M. (2016). Sukcesja indywidualnych gospodarstw rolnych jako czynnik przeobrażeń strukturalnych w polskim rolnictwie. Autoreferat rozprawy doktorskiej przygotowanej pod kier. prof. M.A. Sikorskiej, maszynopis. Warszawa: IERiGŻ-PIB.

GUS (2014). Charakterystyka gospodarstw rolnych $w 2013 r$. Informacje i Opracowania Statystyczne. Warszawa: GUS.

GUS (2017). Charakterystyka gospodarstw rolnych w $2016 r$. Informacje i Opracowania Statystyczne. Warszawa: GUS.

Józwiak, W. (2013). Polskie rolnictwo i gospodarstw rolne w pierwszej i drugiej dekadzie XXI wie$k u$. Program Wieloletni 2011-2014, No. 87, Warszawa: IERiGŻ-PIB.

Józwiak, W. (2017). Gospodarstwa rolne osób fizycznych na rozdrożu. Skąd się biora i dokad zmierzaja. Materiały do referatu pod tym samym tytułem wygłoszonego na seminarium IERiGZ̈-PIB w dniu 03.03.2017 r.

Józwiak, W. (ed.). (2017). Przedsiębiorstwo i gospodarstwo rolne wobec zmian klimatu i polityki rolnej (3). Program Wieloletni 2015-2019, No. 51. Warszawa: IERiGŻ-PIB.

Józwiak, W., Sobierajewska, J., Zieliński, M., Ziętara, W. (2019). Poziom dochodowości pracy a możliwości rozwoju gospodarstw rolnych w Polsce. Zagadnienia Ekonomiki Rolnej, No. 2(359), pp. 28-42.

Kleinhanss, W. (2015). Konkurencyjność głównych typów gospodarstw rolniczych w Niemczech. Zagadnienia Ekonomiki Rolnej, nr 1(342), pp. 24-39.

Kulawik, J., Płonka, R. (2014). Subsydia i efektywność ekonomiczno-finansowa a typ produkcyjny gospodarstw. Zagadnienia Ekonomiki Rolnej, No. 3(340), pp. 3-19.

Manteuffel, R. (1981). Racjonalizacja produkcji w gospodarstwie rolnym. Warszawa: Ludowa Spółdzielnia Wydawnicza.

Runowski, H. (2018). Zróżnicowanie dochodów ludności rolniczej między krajami Unii Europejskiej i kierunki ich zmian. Wieś i Rolnictwo, No. 2(179), pp. 65-84.

Statistisches Jahrbuch über Ernährung, Landwirtschaft und Forsten 2015 (2016). Münster Landwirtschafts Verlag.

Sikorska, A. (2013). Przemiany w strukturze agrarnej indywidualnych gospodarstw rolnych. Warszawa: IERiGŻ-PIB.

Steffen, G. (2001). Wielkość i organizacja rodzinnych gospodarstw rolniczych $w$ Niemczech. Warszawa: Wydawnictwo SGGW.

Tomczak, F. (2004). Od rolnictwa do agrobiznesu. Transformacja gospodarki rolniczo-żywnościowej Stanów Zjednoczonych Ameryki Północnej. Warszawa: Wydawnictwo SGGW.

Woś, A. (ed.). (1998). Encyklopedia agrobiznesu. Warszawa: Fundacja Innowacja, Wyższa Szkoła Społeczno-Ekonomiczna.

Ziętara, W. (2017). Pozycja konkurencyjna polskich gospodarstw z uwzględnieniem typów rolniczych. Roczniki Naukowe SERiA, Vol. XIX, Issue 3, pp. 319-324.

Ziętara, W., Adamski, M. (2018). Konkurencyjność polskich gospodarstw mlecznych na tle gospodarstw z wybranych krajów Unii Europejskiej. Zagadnienia Ekonomiki Rolnej, No. 1(254), pp. 56-79. 
Ziętara, W., Mirkowska, Z. (2019). Pozycja konkurencyjna polskich gospodarstw nastawionych na chów trzody chlewnej. Zagadnienia Ekonomiki Rolnej, No. 1(358), pp. 44-63.

Żmija, D. (2016). Wpływ wspólnej polityki rolnej Unii Europejskiej na funkcjonowanie małych gospodarstw rolnych. Warszawa: Difin.

http://ec.europa.eu/eurostat/data/database (access date: 24.04.2018). 


\title{
PROCESY DOSTOSOWAWCZE \\ W WYBRANYCH TYPACH GOSPODARSTW ROLNYCH W ZALEŻNOŚCI OD ICH SYTUACJI DOCHODOWEJ
}

\begin{abstract}
Abstrakt
$W$ artykule przedstawiono możliwości rozwojowe gospodarstw $w$ grupach wydzielonych wedtug poziomu dochodu z gospodarstwa w przeliczeniu na jednostke nakładów pracy własnej rolnika i członków jego rodziny oraz według typów rolniczych. Wedtug kryterium dochodu wydzielono gospodarstwa:

- pomocnicze, w których dochód z gospodarstwa $w$ przeliczeniu na godzinę nakładu pracy własnej rodziny rolniczej $w$ posiadanym gospodarstwie byt niższy od stawki opłaty pracy najemnej $w$ rolnictwie;

- przejściowe (na rozdrożu), w których dochód ów byt wyższy od stawki opłaty pracy najemnej $w$ rolnictwie, ale niższy od stawki opłaty $w$ gospodarce narodowej;

- rozwojowe, $w$ których dochód ten byt równy lub wyższy stawce opłaty pracy $w$ gospodarce narodowej.

Analiza objęto typy gospodarstw wyspecjalizowanych w: uprawach polowych, uprawach trwatych, uprawach warzywniczych, chowie krów mlecznych, chowie zwierząt ziarnożernych $i$ z produkcja mieszana. Źródłem materiatów badawczych byt panel gospodarstw objętych monitoringiem Polskiego FADN w latach 2009-2016. Grupy wydzielono zgodnie z metodyka FADN. Możliwości rozwojowe analizowanych grup gospodarstw określono wskaźnikiem konkurencyjności (Wk). W analizowanym okresie znaczacy byt udziat gospodarstw pomocniczych, zawarty $w$ przedziale od 24,5\% (gospodarstwa mleczne) do 43,1\% (gospodarstwa z produkcja mieszana). Udziat ten zwiększat się $w$ kolejnych okresach. Gospodarstwa te nie miały zdolności rozwojowych. Udziat gospodarstw przejściowych byt niewielki, Mieścit się w przedziale od 8,5\% (uprawy polowe) do $13 \%$ (z produkcją mieszana). Gospodarstwa tej grupy również nie wykazywaty zdolności rozwojowych. Udziat gospodarstw rozwojowych byt dość zróżnicowany, zawarty $w$ przedziale od 44,4\% (z produkcja mieszana) do $69 \%$ (z uprawami polowymi). Zastosowane kryterium podziału gospodarstw wedtug poziomu dochodu z gospodarstwa na jednostkę nakładów pracy własnej rolnika i członków jego rodziny zwiększa możliwości ich analizy.
\end{abstract}

Słowa kluczowe: gospodarstwa rolne, dochód z gospodarstwa, gospodarstwa pomocnicze, przejściowe i rozwojowe, typy rolnicze.

Accepted for print: 11.12.2019.

Unless stated otherwise all the materials on the website are available under the Creative Commons Attribution 4.0 International license.

Some rights reserved to the Institute of Agricultural and Food Economics - National Research Institute.

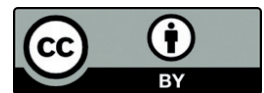

